\title{
Severe Gammaherpesvirus-Induced Pneumonitis and Fibrosis in Syngeneic Bone Marrow Transplant Mice Is Related to Effects of Transforming Growth
} Factor- $\beta$

\author{
Stephanie M. Coomes, ${ }^{*}$ Sara Farmen, ${ }^{\dagger}$ \\ Carol A. Wilke, ${ }^{\ddagger}$ Yasmina Laouar, ${ }^{\S}$ and \\ Bethany B. Moore ${ }^{\ddagger \S}$ \\ From the Graduate Program in Immunology* and the \\ Departments of Pathology, ${ }^{\dagger}$ Internal Medicine, ${ }^{\ddagger}$ and Microbiology \\ and Immunology, ${ }^{\complement}$ University of Michigan, Ann Arbor, Michigan
}

Pulmonary infections and pneumonitis occur frequently after hematopoietic stem cell transplantation. Using a syngeneic mouse model of bone marrow transplantation (BMT), we have previously demonstrated that BMT mice are more susceptible to acute gammaherpesvirus 68 (MHV-68) replication at day 7 after infection. By day 21, the virus is latent in lungs of BMT and control mice, and there is no difference in viral load. Despite similar latent viral load, BMT mice develop severe pneumonitis associated with reduced oxygen saturation, fibrosis, peripheral inflammation, hyaline membranes, and foamy alveolar macrophages, a phenotype that persists for 7 weeks after infection. BMT mice demonstrate increased bronchoalveolar lavage (BAL) cells, and this population is enriched in neutrophils and T cells. Alternatively, activated macrophages appear earlier than do classically activated macrophages. BAL fluid from BMT mice at day 21 after infection contains increased levels of hydrogen peroxide, nitrite, and transforming growth factor- $\beta$ (TGF- $\beta$ ). Mice expressing the dominant-negative transgene dn-TGF $\beta$ RII in multiple cell types were used as BMT donors. BMT mice with T-cell dnTGF $\beta$ RII are largely protected from the pneumonitis phenotype, whereas mice with CD11c-dnTGF $\beta$ RII BMT mice are only modestly protected from pneumonitis. Protection in BMT mice with T-cell dnTGF $\beta R I$ is associated with decreased TGF- $\beta$ derived from parenchymal cells in the BAL fluid, lower nitrite levels, and reduced apoptosis, whereas alternatively activated macrophage markers are unchanged. (Am J Pathol 2011, 179:2382-2396; DOI: 10.1016/j.ajpath.2011.08.002)

Hematopoietic stem cell transplantation (HSCT) is an important therapy in the treatment of many malignant diseases and some inherited and autoimmune disorders. ${ }^{1}$ In preparation for transplantation, patients are frequently treated using a myeloablative conditioning regimen including chemotherapy and/or total body irradiation. After conditioning, patients receive an infusion of hematopoietic stem cells from a donor (allogeneic transplant) or their own cells that had been harvested before conditioning (autologous transplant). These cells are derived from bone marrow, cord blood, or mobilized peripheral cells. ${ }^{1,2}$ Several serious transplant-related complications can occur after HSCT, and pulmonary complications are a substantial cause of morbidity and mortality in transplant recipients. $^{3-5}$

Pulmonary complications can be infectious or noninfectious. Infectious pneumonia can be caused by fungi (eg, Aspergillus), bacteria, or viruses including cytomegalovirus, respiratory viruses, or adenovirus. ${ }^{6}$ Noninfectious pulmonary complications that occur after transplantation include idiopathic pneumonia syndrome, which involves pneumonia and alveolar injury in the absence of infection in both allogeneic ${ }^{7}$ and autologous ${ }^{7-9}$ transplantation procedures, and bronchiolitis obliterans as a manifestation of graft-versus-host disease (GvHD) in allogeneic transplantations. ${ }^{7}$ Both total body irradiation and chemotherapeutic agents used in conditioning, including cyclophosphamide and busulfan, can cause pul-

Supported by grants Al065543 and HL087846 from the NIH and by the Herman and Dorothy Miller Fund for Innovative Immunology Research.

Accepted for publication August 1, 2011

Supplemental material for this article can be found on http://ajp. amjpathol.org or at doi: 10.1016/j.ajpath.2011.08.002

Address reprint requests to Bethany B. Moore, Ph.D., 4053 BSRB, 109 Zina Pitcher PI, Ann Arbor, Ml 48109-2200. E-mail: Bmoore@umich.edu. 
monary toxicity. ${ }^{10}$ In addition, HSCT recipients demonstrate abnormal pulmonary function test results over the long term after transplantation. ${ }^{11,12}$

Mouse models of bone marrow transplantation (BMT) enable controlled study of how conditioning and transfer of hematopoietic stem cells alters subsequent pulmonary immune responses in the transplant host. The syngeneic mouse model enables study of conditioning and transplantation in the absence of the confounding effects of GvHD or immunosuppressive drug therapy. In a syngeneic BMT mouse model, we have previously demonstrated that mice undergoing BMT are more susceptible to lytic pulmonary infection with the murine gammaherpesvirus 68 (MHV-68), even after reconstitution of immune cell numbers. Our data suggested that this increased susceptibility was related to decreased interferon- $\gamma$ production by CD4 cells and increased transforming growth factor (TGF)- $\beta 1$ in the lung. ${ }^{13}$ In the present study, we characterized virus-induced pneumonitis that occurs during MHV-68 latency ${ }^{14}$ in BMT mice and persists even 49 days after infection, long after the lytic infection has resolved. In our model, lungs from latently infected BMT mice were characterized by fibrosis, foamy alveolar macrophages, peripheral inflammation, and diffuse alveolar damage. Our data suggested that TGF- $\beta$ has an important role in promoting pneumonitis, which supports a previous report of herpes simplex type 1-induced pneumonitis in allogeneic mice with GvHD that could be alleviated with use of anti-TGF- $\beta$ therapy..$^{15}$ We observed that blocking of TGF- $\beta$ signaling in the BMT setting can alleviate development of pneumonitis during latent MHV-68 infection.

\section{Materials and Methods}

\section{Mice}

C57BL/6 mice were purchased from Jackson Laboratory (Bar Harbor, ME). Mice expressing dominant-negative TGF- $\beta$ receptor II (dnTGF $\beta$ RII) under the permissive CD4 promoter ${ }^{16}$ backcrossed onto the C57BL/6 background were obtained from Jackson Laboratory and bred at the University of Michigan. Because of the nature of the promoter construct, these mice lack functional TGF- $\beta$ receptor II in both CD4 and CD8 T cells. ${ }^{16}$ Mice expressing the same construct under the CD11c promoter ${ }^{17}$ were bred at the University of Michigan. Mice were housed in specific pathogen-free conditions and were monitored daily by veterinary staff. Experiments were approved by the University of Michigan Committee on the Use and Care of Animals.

\section{Bone Marrow Transplantation}

BMT was performed as described previously. ${ }^{13,18,19}$ In brief, recipient mice were treated with 13 Gy total body irradiation using a cesium 137 irradiator, delivered in two doses separated by 3 hours. Donor whole bone marrow cells, $5 \times 10^{6}$, from a genetically identical donor in $0.2 \mathrm{~mL}$ Dulbecco's modified Eagle's medium (DMEM; Invitrogen Corp., Carlsbad, CA) without serum were injected into irradiated mice via the tail vein. Mice were given acidified water ( $\mathrm{pH}$ 3.3) for the first 3 weeks after BMT. Total numbers of hematopoietic cells were fully reconstituted in the lungs and spleen at 5 weeks after BMT, with lung lymphocytes $93 \%$ donor-derived at that time. ${ }^{13}$ All infections were initiated at 5 to 6 weeks after BMT.

\section{MHV-68 Infection}

MHV-68, $5 \times 10^{4}$ plaque-forming units (pfu) (American Type Culture Collection, Manassas, VA), was diluted in $20 \mu \mathrm{L}$ PBS and delivered intranasally in mice that had been anesthetized using ketamine and xylazine. In some experiments, mice were infected with different dosages of virus, as noted in the text.

\section{Real-Time RT-PCR}

Real-time RT-PCR was performed using a thermocycler (ABI Prism 7000; Applied Biosystems, Inc., Foster City, CA) using a previously described protocol. ${ }^{19}$ Gene-specific primers and probes (Table 1) were designed using Primer Express software (Applied Biosystems, Inc.).

\section{Histologic Analysis}

Lungs were harvested for histologic analysis as previously described. ${ }^{20}$ In brief, lungs from euthanized animals were perfused with PBS, inflated with $1 \mathrm{~mL} 10 \%$ buffered formalin, removed, and fixed for 6 to 24 hours in formalin. Lungs were placed in ethanol for at least 24 hours, embedded in paraffin, and cut into $3-\mu \mathrm{m}$ sections. Sections were placed on slides and stained using H\&E or Masson's trichrome blue for collagen deposition.

\section{Apoptosis Staining}

Lung sections were stained with fluorescein isothiocyanate-labeled E-cadherin as a marker for epithelial cells and an in situ cell death detection kit (TUNEL-TMR red; Roche Applied Science, Indianapolis, IN) according to the manufacturer's instructions. Apoptotic cells were counted in four high-power fields in two tissue sections per group.

\section{Pathology Scoring}

H\&E- and trichrome-stained slides were analyzed by a pathologist (S.F.) in a blinded fashion. Lungs were scored for severity of fibrosis, perivascular inflammation, and peripheral inflammation on a scale of 0 (absent) to 3 (severe). The presence of foamy alveolar macrophages and hyaline membranes was graded as 0 (absent) or 1 (present). The scores for each factor were totaled to give a pathology score, with 11 indicating the most severe phenotype.

\section{Oxygen Saturation Measurements}

Oxygen saturation was measured using a pulse oximeter (Mouse Ox; Starr Life Sciences Corp., Oakmont, PA) 
Table 1. Primers and Probes for Semiquantitative Real-Time RT-PCR

\begin{tabular}{|c|c|c|}
\hline Gene & Oligo & Primer sequence \\
\hline \multirow[t]{3}{*}{ DNA polymerase (ORF9) } & Forward & $5^{\prime}$-ACAGCAGCTGGCCATAAAGG-3' \\
\hline & Reverse & $5^{\prime}-$ TCCTGCCCTGGAAAGTGATG-3' \\
\hline & Probe & $5^{\prime}$-CCTCTGGAATGTTGCCTTGCCTCCA-3' \\
\hline \multirow{3}{*}{ Envelope gene gB (ORF8) } & Forward & $5^{\prime}-$ CGCTCATTACGGCCCAAA-3' \\
\hline & Reverse & $5^{\prime}-$ ACCACGCCCTGGACAACTC- $3^{\prime}$ \\
\hline & Probe & $5^{\prime}-$ TTGCCTATGACAAGCTGACCACCA-3' \\
\hline \multirow[t]{3}{*}{$\beta$-Actin } & Forward & $5^{\prime}-$ CCGTGAAAAGATGACCCAGATC- $3^{\prime}$ \\
\hline & Reverse & $5^{\prime}$-CACAGCCTGGATGGCTACGT-3' \\
\hline & Probe & $5^{\prime}-$ TTTGAGACCTTCAACACCCCCAGCCA-3' \\
\hline \multirow[t]{3}{*}{ M3 } & Forward & $5^{\prime}-$ AGTGGGCTCACGCTGTACTTGT-3' \\
\hline & Reverse & 5'-TGTCTCTGCTCACTCCATTTGG-3' \\
\hline & Probe & $5^{\prime}$-CATGGGCAAGTGTTCATCTTAGCC-3' \\
\hline \multirow[t]{3}{*}{ Collagen 1} & Forward & $5^{\prime}-$ TGACTGGAAGAGCGGAGAGTACT-3' \\
\hline & Reverse & 5'-GGTCTGACCTGTCTCCATGTTG-3' \\
\hline & Probe & $5^{\prime}-$ CTGCAACCTGGACGCCATCAAGG- $3^{\prime}$ \\
\hline \multirow[t]{3}{*}{ Collagen 3} & Forward & 5'-GGATCTGTCCTTTGCGATGAC-3' \\
\hline & Reverse & 5-GCTGTGGGCATATTGCACAA-3' \\
\hline & Probe & $5^{\prime}-\mathrm{TGCCCCAACCCAGAGATCCCATTT-3^{ \prime }}$ \\
\hline \multirow[t]{3}{*}{ iNOS } & Forward & $5^{\prime}-$ ACATCAGGTCGGCCATCACT-3' \\
\hline & Reverse & 5'-CGTACCGGATGAGCTGTGAAT-3' \\
\hline & Probe & $5^{\prime}-$ CCCCAGCGGAGTGACGGCA-3' \\
\hline \multirow[t]{3}{*}{ Arginase 1} & Forward & $5^{\prime}-\mathrm{ACCACAGTCTGGCAGTTGGAA}-3^{\prime}$ \\
\hline & Reverse & $5^{\prime}-\mathrm{GCATCCACCCAAATGACACA-3^{ \prime }}$ \\
\hline & Probe & $5^{\prime}-\mathrm{CTGGCCACGCCAGGGTCCAC-3^{ \prime }}$ \\
\hline
\end{tabular}

according to the manufacturer's instructions. In brief, mice were anesthetized, and their neck hair was removed using a depilatory cream. After 24 hours, collar clip sensors were placed on mice that were awake, and oxygen saturation was measured as an average over 15 seconds per mouse.

\section{Bronchoalveolar Lavage}

Bronchoalveolar lavage (BAL) was performed as previously described, with modifications. ${ }^{19}$ In brief, cells were isolated from the alveolar space via lavage using $20 \mathrm{~mL}$ PBS containing $5 \mathrm{mmol} / \mathrm{L}$ EDTA in successive 1-mL aliquots. BAL fluid was harvested by instilling 1 $\mathrm{mL}$ PBS containing $5 \mathrm{mmol} / \mathrm{L}$ EDTA into lung and removing fluid via suction. The BAL fluid was centrifuged to remove cells. In some experiments, alveolar macrophages were isolated via plastic adherence in serumfree medium for 2 hours. BAL fluid or cell supernatants were assayed for total TGF- $\beta 1$ levels after acidification and neutralization using the DuoSet ELISA Development System kit (R\&D Systems, Inc., Minneapolis, MN), for hydrogen peroxide using the Amplex Red Hydrogen Peroxide/Peroxidase Assay Kit (Molecular Probes, Inc., Eugene, OR), and for nitrite using the Griess Reagent System (Promega Corp., Madison, WI) following the manufacturers' instructions.

\section{Lung Collagenase Digestion}

Lung leukocytes were isolated from collagenase and DNase digested lungs as previously described. ${ }^{13} \mathrm{~B}$ and $T$ cells were collected via magnetic sorting using antiCD3 beads or biotinylated CD19 antibody followed by incubation with streptavidin beads (Miltenyi Biotec, Inc., Auburn, CA). Cell supernatants were assayed for TGF- $\beta$ using and enzyme-linked immunosorbent assay (ELISA).

\section{Anti-CD25 Treatment}

On day 10 after infection, BMT mice were subjected to $100 \mu \mathrm{L}$ anti-CD25 ascites or $100 \mu \mathrm{g}$ isotype control.

\section{Flow Cytometry}

Cells, $1 \times 10^{6}$, were stained for flow cytometry using fluorochrome-conjugated antibodies against the cell surface markers CD4, CD8, and CD19 (BD Biosciences, San Jose, CA) after incubation with anti-CD16/ CD32 (FcBlock; BD Biosciences). Data were analyzed using flow cytometry analysis software (FlowJo, version 7.5; Tree Star, Inc., Ashland, OR).

\section{Hydroxyproline Assays}

Collagen content was measured in lungs using a hydroxyproline assay. In brief, lungs were homogenized in $1 \mathrm{~mL}$ PBS and hydrolyzed via addition of $1 \mathrm{~mL} 12 \mathrm{~N}$ hydrochloric acid. Samples were then baked at $110^{\circ} \mathrm{C}$ for 12 hours. Five-microliter aliquots were then assayed by adding cloramine $\mathrm{T}$ solution for 20 minutes followed by development with Erlich's reagent at $65^{\circ} \mathrm{C}$ for 15 minutes, as previously described. ${ }^{21}$ Absorbance was measured at $550 \mathrm{~nm}$, and the amount of hydroxyproline was determined against a standard curve generated using known 
concentrations of a cis-hydroxyproline standard (SigmaAldrich, St. Louis, MO).

\section{Alveolar Epithelial Cell Purification}

Type II alveolar epithelial cells (AECs) were isolated after dispase digestion of the lower airways and removal of CD32- and CD45-expressing cells via magnetic sorting. Fibroblasts were removed via overnight adherence to plastic, before AECs were enumerated and plated on fibronectin-coated plates, as described previously. ${ }^{22}$

\section{Viral Genome Quantification}

DNA was prepared from MHV-68-infected lungs using the DNeasy Blood and Tissue Kit (Qiagen, Inc., Valencia, CA), and PCR was performed to detect the glycoprotein $\mathrm{B}(\mathrm{gB})$ viral coding sequence as previously described. ${ }^{23,24}$ Values were compared with a standard curve consisting of $\mathrm{gB}$ plasmid DNA diluted at known copy numbers. Reported values were normalized to 100 ng input DNA for each reaction. For $g B D N A$ analysis, the forward primer was 5'-GGCCCAAATTCAATTTGCCT-3', the reverse primer was $5^{\prime}$-CCCTGGACAACTCCTCAAGC$3^{\prime}$, and the probe was 5'-6-(FAM)-ACAAGCTGACCACCAGCGTCAACAAC-3'(TAMRA).

\section{Reagents}

The complete medium used was DMEM (Lonza Walkersville, Inc., Walkersville, MD) with $10 \%$ fetal bovine serum (Fisher Scientific, Pittsburgh, PA), 1\% penicillin-streptomycin (Gibco-BRL, Invitrogen Corp.), 1\% L-glutamine (Fisher Scientific), and $0.1 \%$ amphotericin B (Lonza Walkersville, Inc.). The serum-free medium used was DMEM with $1 \%$ bovine serum albumin (Sigma-Aldrich), 1\% penicillin-streptomycin, $1 \%$ L-glutamine, and $0.1 \%$ amphotericin B.

\section{Statistical Analysis}

Statistical significance between the two groups was measured using Student's $t$-test with Prism 5 software (GraphPad Software, Inc., La Jolla, CA). Data are given as mean \pm SEM. $P<0.05$ was considered significant.

\section{Results}

\section{BMT and Control Mice Demonstrate an Equivalent Viral Load at Day 21 after Infection}

We have previously demonstrated that syngeneic BMT mice are more susceptible to lytic MHV-68 infection measured at day 7 after challenge despite complete immune cell reconstitution. ${ }^{13}$ To determine whether BMT mice exhibited an increased viral load during MHV-68 latency, syngeneic BMT mice at 5 weeks after transplantation and control mice that had not undergone transplantation were infected with $5 \times 10^{4} \mathrm{pfu}$ MHV-68 intranasally, and lungs
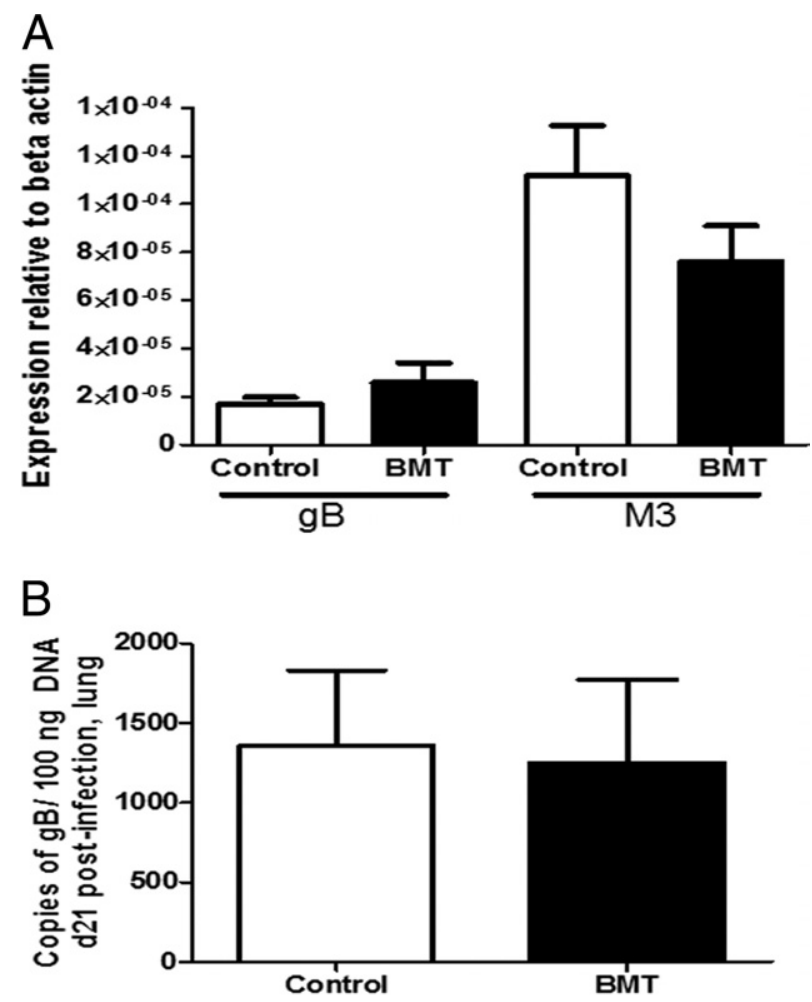

Figure 1. BMT and control mice have similar latent viral load at day 21 after infection with MHV-68. Control and syngeneic BMT mice at 5 weeks after transplantation were infected with $5 \times 10^{4} \mathrm{pfu}$ MHV-68 intranasally. A: At day 21 after infection, lungs were harvested for RNA, and expression of the lytic viral envelope glycoprotein gene $g B$ and the predominantly latent viral gene $M 3$ were measured using real-time RT-PCR. There was no significant difference in expression of either of these genes between BMT and control mice ( $n=11$ mice per group; data representative of two independent experiments). B: At day 21 after infection, lungs were harvested for DNA, and copy number of viral $g B$ gene was quantified using real-time PCR using a standard with known quantities of $g B$ DNA. There was no significant difference in latent viral genome load between BMT and control groups ( $n=3$ mice per group; data representative of two independent experiments).

were harvested at day 21 after infection, a time when MHV-68 is latent in the lung. ${ }^{25}$ Using real-time RT-PCR on whole-lung RNA, we observed that expression of the predominantly latent viral gene $M 3$ was expressed at much higher levels than the lytic viral gene $g B$, which suggests that MHV-68 was latent at this time in both groups of mice. In addition, no significant difference was observed between levels of either gene in lungs of BMT or control mice (Figure 1A). To confirm that there was no difference in latent viral load, DNA was harvested from lungs at day 21 after infection, and copy numbers of the viral genome were quantified using real-time PCR and a plasmid standard containing known copy numbers of $g B$ DNA. No significant difference was observed in quantities of viral genomes between BMT and control mice (Figure 1B).

\section{BMT Mice Exhibit Histologic Changes in Lung during Latent MHV-68 Infection}

Despite observing no difference in viral load at day 21 after infection with MHV-68, lungs from BMT mice dem- 


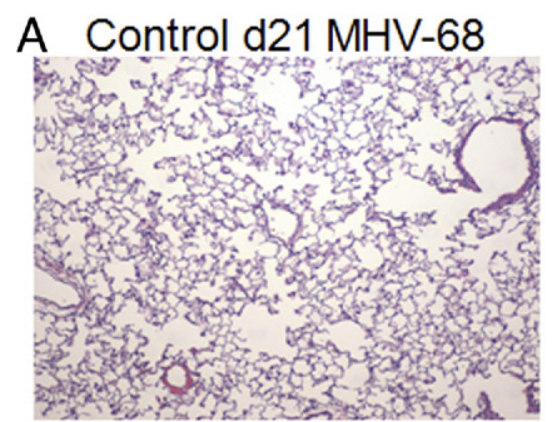

B

\begin{tabular}{|c|c|c|}
\hline Pathological Features & $\underline{\text { Control }}$ & $\underline{\text { BMT }}$ \\
\hline Mild to moderate fibrosis & $0 / 5$ & $4 / 4$ \\
\hline Foamy alveolar macrophages & $1 / 5$ & $4 / 4$ \\
\hline Perivascular inflammation & $5 / 5$ & $4 / 4$ \\
\hline $\begin{array}{c}\text { Moderate/ extensive peripheral } \\
\text { inflammation }\end{array}$ & $0 / 5$ & $4 / 4$ \\
\hline $\begin{array}{c}\text { Hyaline membranes/ Diffuse } \\
\text { alveolar damage }\end{array}$ & $0 / 5$ & $4 / 4$ \\
\hline
\end{tabular}

BMT d21 MHV-68

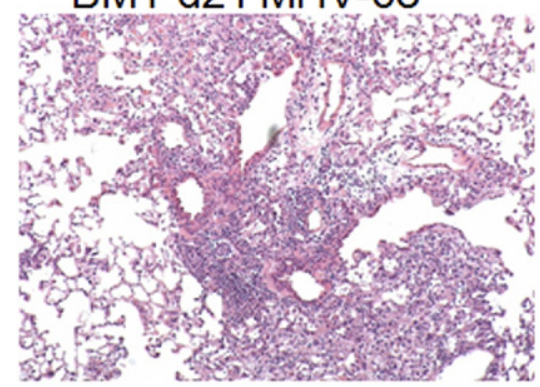

BMT Uninfected

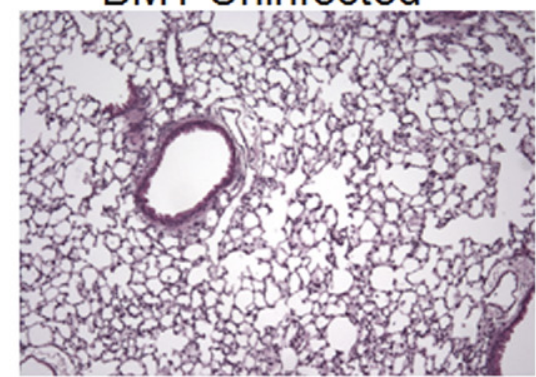

C

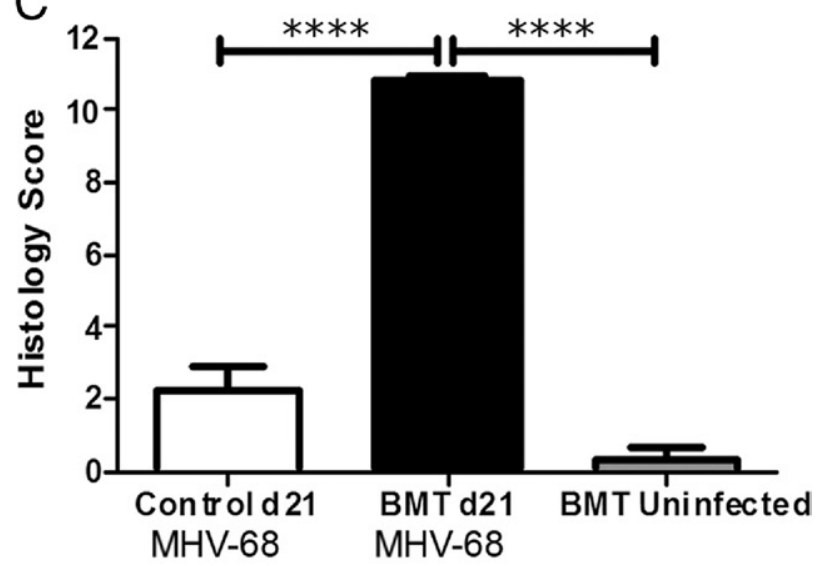

Figure 2. BMT mice, but not control mice, demonstrated virus-induced lung disease during latent MHV- 68 infection. A: Lungs from syngeneic BMT and control mice were harvested for histologic analysis, either at day 21 after infection with MHV- 68 or uninfected at 8 weeks after BMT, and sections were stained using H\&E ( $\times 100$ magnification). B: H\&E-stained lung sections from BMT and control mice at day 21 after infection with MHV- 68 were analyzed for the presence of pathologic features in a blinded fashion ( $n=5$ control mice and 4 BMT mice; data representative of two separate experiments). C: Lung sections were scored on the basis of presence and severity of pathologic features, and a composite score was generated for each mouse. A mean histology score was generated for each group ( $n=7$ infected BMT mice, 5 infected control mice, and 3 uninfected BMT; data representative of three separate experiments; $\left.{ }^{* * * * *} P \leq 0.0001\right)$

onstrated significant histologic changes compared with lungs from control mice that did not undergo transplantation. Lung sections from BMT and control mice were stained using $\mathrm{H} \& \mathrm{E}$ at day 21 after infection (Figure 2A). H\&E- and trichrome-stained slides were analyzed in a blinded fashion by a pulmonary pathologist (S.F.), and lungs from BMT mice exhibited mild to moderate fibrosis, foamy alveolar macrophages, peripheral inflammation, and diffuse alveolar damage. Both control and BMT mice exhibited perivascular inflammation (Figure 2B). Lungs were scored on a scale of 0 (normal lung) to 11 (most severe disease) (see Materials and Methods). Compared with control mice, BMT mice demonstrated a significant increase in histology score (Figure 2C). To determine whether disease observed in BMT mice was virus-induced or due only to the conditioning regimen, lung sections from uninfected BMT mice at 8 weeks after transplantation were analyzed. H\&E staining demonstrated that uninfected BMT lungs did not exhibit the pathologic features observed in latently infected BMT lungs (Figure 2A). In addition, compared with latently infected BMT mice, uninfected BMT mice demonstrated a significantly lower histology score (Figure 2C).

\section{Latently Infected BMT Lungs Are Fibrotic}

To determine whether MHV-68 induced a fibrotic response in the lungs of BMT mice, lung sections from BMT and control mice at day 21 after infection were harvested and stained with trichrome. Blue coloration indicating collagen deposition was observed throughout the lungs in the BMT mice but not in the control mice. Lungs from uninfected BMT mice at 8 weeks after transplantation did not show abnormal collagen deposition (Figure 3A). To quantify collagen expression in lungs of BMT and control mice in response to latent MHV-68 infection, we performed hydroxyproline assays to quantify collagen deposition. Figure $3 \mathrm{~B}$ demonstrates that, compared with control mice, BMT mice exhibited significantly increased collagen content in their lungs at day 21 after infection. In addition, RNA was harvested from lungs at day 21 after infection, and expression of collagen 1 and collagen 3 transcripts was determined using real time RT-PCR. BMT lungs expressed an approximate twofold increase in both genes (Figure 3C). Thus, lungs from latently infected BMT mice are fibrotic. To determine whether the pneumonitis and fibrotic phenotype persisted, we infected BMT and control mice and harvested their lungs for histologic analysis at day 49 after infection. At that time, we observed persistence of pneumonitis and fibrosis, as demonstrated by H\&E and trichrome staining, 

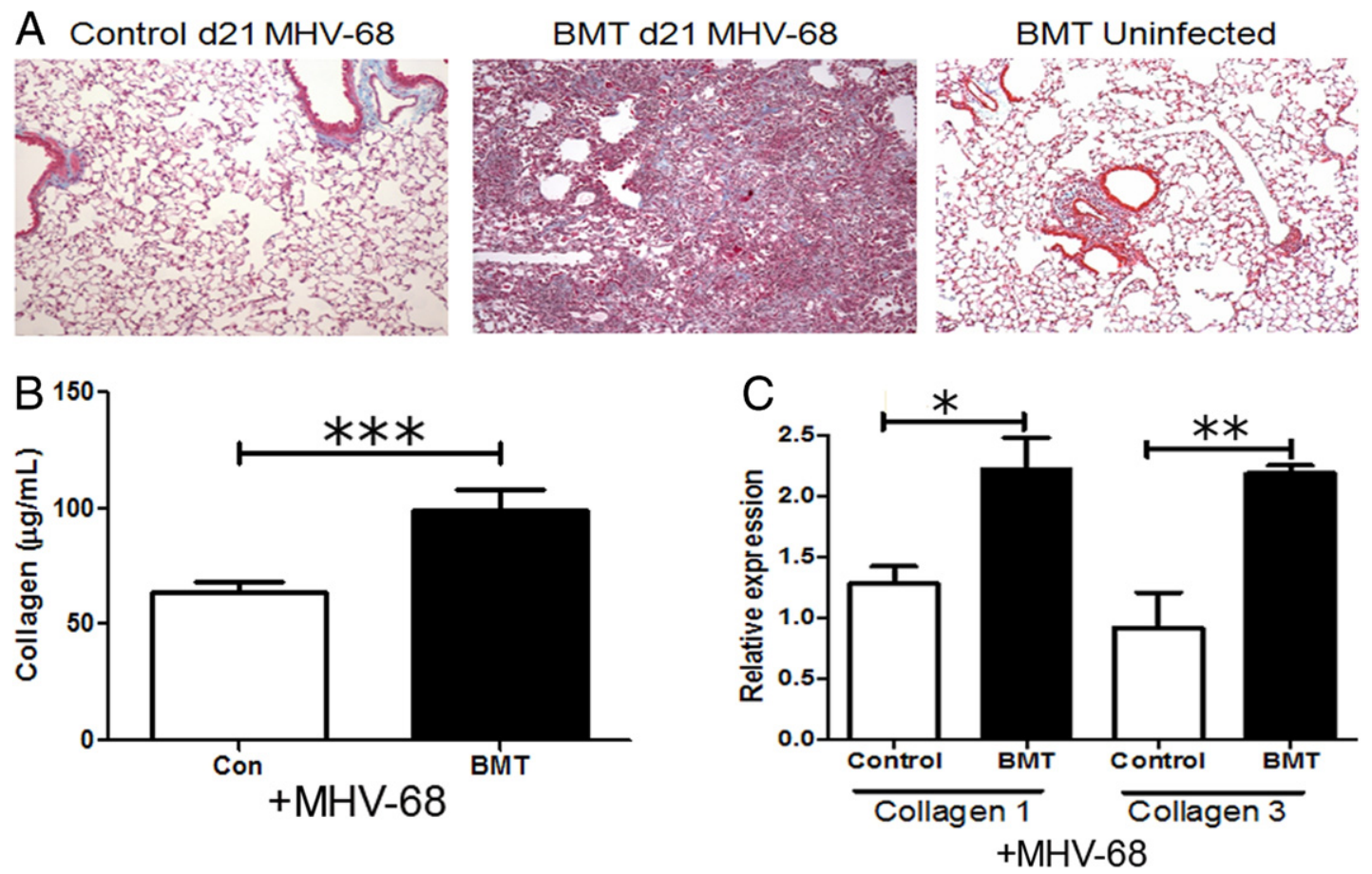

Figure 3. BMT lungs, but not control lungs, are fibrotic during latent MHV-68 infection. Syngeneic BMT and control mice were infected with $5 \times 10^{4}$ pfu MHV- 68 , and lungs were harvested at day 21 after infection. A: Lung sections from infected or not infected BMT and control mice were stained using Masson's trichrome (magnification $\times 100)$. B: Collagen content in lungs of control or BMT mice at day 21 after infection were measured using a hydroxyproline assay $(n=5)$. ${ }^{*} * * * 2=0.0057$. C: Lungs were harvested for RNA, and expression of collagen 1 and collagen 3 was analyzed using real-time RT-PCR. Expression was normalized to the control group for each gene. Collagen 1 and collagen 3 were significantly increased in BMT lungs $\left(n=3\right.$ mice per group; ${ }^{*} P=0.0348$ and ${ }^{* *} P=0.0129$, respectively; data representative of two independent experiments).

and the histology score was significantly increased in BMT mice compared with control mice (see Supplemental Figure S1 at $h$ ttp://ajp.amjpathol.org).

\section{BMT Mice Have Increased Inflammatory Cells in the Alveolar Space during Latent MHV-68 Infection}

To characterize the cells present in the alveolar space at day 21 after infection, BAL was performed in BMT and control mice, and total cells were counted. There was a significant increase in total cell numbers harvested from BMT lungs compared with control lungs (Figure 4A). BAL cells from control mice were largely monocytes and macrophages, as determined via differential counting. However, BMT BAL cells included an influx of lymphocytes and neutrophils (Figure 4B). To determine lymphocyte populations in the alveolar space, cells were analyzed using flow cytometry. Compared with control mice, BMT mice demonstrated significant increases in numbers of both CD4 and CD8 cells, and few B cells were present in either group (Figure 4C).

\section{Reduced Oxygen Saturation in Latently Infected BMT Mice}

To understand whether pneumonitis in BMT mice led to changes in lung physiologic features, we used the
Mouse Ox pulse oximeter (Starr Life Sciences Corp.) to measure oxygen saturation in mice at day 21 after infection. A significant decrease in oxygen saturation was observed in BMT mice compared with control mice (see Supplemental Figure S2 at http://ajp.amjpathol. org). However, there was no difference in oxygen saturation between these groups before infection (data not shown). These data indicate that gammaherpesvirus infection in BMT mice leads to reduced oxygen saturation.

\section{Alveolar Macrophages Show a Mixed Classic and Alternative Activation Phenotype}

Lungs from BMT mice latently infected with MHV-68 contained foamy alveolar macrophages (Figure 2). $H \& E$ staining at $\times 400$ magnification demonstrated these macrophages more clearly (Figure 5A). Because alternative activation of macrophages (reviewed by Gordon and Martine ${ }^{26}$ ) has been implicated in contributing to pulmonary fibrosis in mouse models, ${ }^{27}$ we wondered whether macrophages in our model expressed markers of alternative or classic activation. Alveolar macrophages were harvested from control or BMT mice via plastic adherence, and expression of the classic marker inducible nitric oxide synthesis (iNOS) and the alternative activation marker arginase 1 was determined using real time RT-PCR. A significant in- 

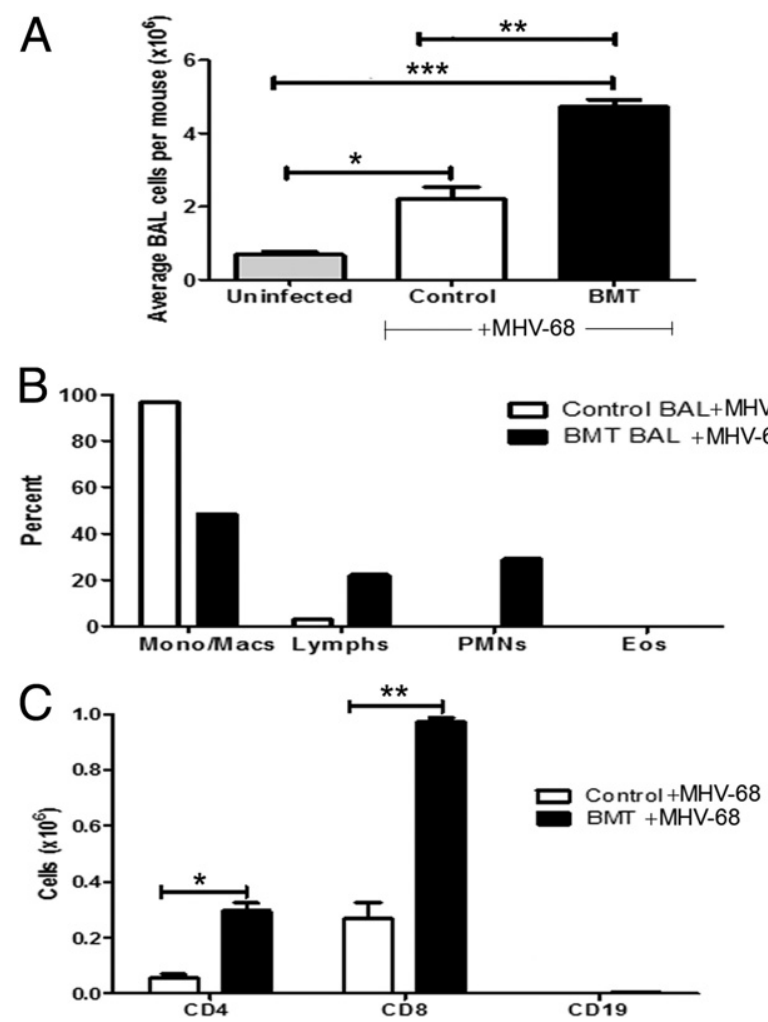

Figure 4. BMT mice demonstrate increased infiltration of inflammatory cells in the alveolar space during latent MHV-68 infection. At day 21 after infection with $5 \times 10^{4}$ pfu MHV-68, cells were harvested from the alveolar space of BMT and control mice using BAL. A: Compared with control mice, BMT mice exhibited a significant increase in total number of cells harvested by BAL (** $P \leq 0.01 ; n=5$ mice per group; data representative of three independent experiments); ${ }^{*} P \leq 0.05 ;{ }^{* * * *} P \leq 0.001$. B: BMT mice have increased percentages of lymphocytes and neutrophils in the alveolar space, as determined by differential counting ( $n=5$ mice per group; data representative of two independent experiments). C: BAL cells were harvested and stained for flow cytometry for CD4, CD8, and CD19. Numbers of CD 4 and CD8 cells were significantly increased in BMT mice $\left({ }^{*} P=0.0166\right.$ and ${ }^{* * *} P=0.0074$, respectively; $n=5$ mice per group; data representative of two independent experiments).

crease was observed in expression of both genes in BMT cells compared with control cells at day 21 after infection (Figure 5B). To determine the kinetics for macrophage activation, we also collected alveolar macrophages on days 9, 13, and 19 after infection. Expression of arginase 1 was significantly elevated by day 13 after infection, whereas expression of iNOS was not elevated until day 21. In addition, the fold increase in arginase 1 was much greater than that noted for iNOS (see Supplemental Figure S3 at http://ajp. amjpathol.org).

Despite the steady increase in arginase 1 expression, alveolar macrophages from BMT mice did not express IL-4 or IL-13 mRNA, cytokines thought to be critical for alternative activation, ${ }^{26}$ at day 21 after infection (data not shown). In addition, IL-4 and IL-13 protein could not be detected using an ELISA in collagenase-digested lungs, and little IL-13 and no IL-4 mRNA could be detected in cultured BAL cells including lymphocytes in BMT mice on day 21 after infection (data not shown).

\section{BAL Fluid from BMT Mice Contains Pro-Fibrotic Mediators}

Because oxidative stress has been implicated in contributing to pulmonary fibrosis in studies in both humans $^{28}$ and mice, ${ }^{29}$ we tested levels of ROS in the BAL fluid of BMT and control mice at day 21 after infection. Levels of $\mathrm{H}_{2} \mathrm{O}_{2}$ and $\mathrm{NO}_{2}{ }^{-}$were significantly increased in BAL fluid from BMT mice compared with control mice (Figure 6, A and B) at day 21 after infection. We next determined whether the level of TGF- $\beta$, a potent pro-fibrotic mediator, ${ }^{30,31}$ was increased in BAL fluid from BMT mice. Our previous studies had demonstrated that whole lung homogenates from uninfected BMT mice at 5 weeks after transplantation had significantly increased total TGF- $\beta 1$ protein. ${ }^{13}$ We now report that at day 21 after infection, compared with control mice, BMT mice demonstrated a significant increase in total TGF- $\beta 1$ protein in BAL fluid (Figure $6 \mathrm{C}$ ).

To determine the kinetics of TGF- $\beta$ secretion, we analyzed BAL fluid for TGF- $\beta$ levels on days $9,13,19$, and 21 after infection. Levels were increasing by day 19 after infection, and reached statistical significance by day 21 (Supplemental Figure S4 at http://ajp. amjpathol.org). Generation of ROS, as assessed by nitrite production in BAL fluid, mirrored the increases in TGF- $\beta$ levels (see Supplemental Figure S4 at $h$ ttp:// ajp.amjpathol.org).
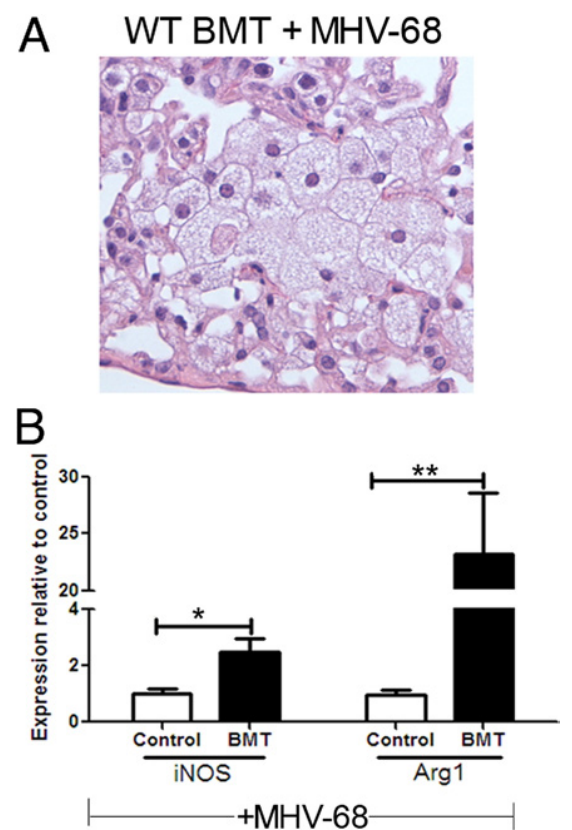

Figure 5. BMT alveolar macrophages are foamy and express increased iNOS and arginase 1 . BMT and control mice were infected with $5 \times 10^{4}$ pfu MHV-68 for 21 days. A: H\&E-stained BMT lung section demonstrates foamy alveolar macrophages (magnification $\times 400$ ). B: BAL cells from infected BMT and control mice were plated for 2 hours in serum-free DMEM. Nonadherent cells were removed, and adherent cells were harvested for RNA. Expression of the classic activation marker iNOS and an alternative activation marker arginase 1 (Arg1) were both significantly increased in BMT cells ( ${ }^{*} P=0.0270$ and ${ }^{* *} P=0.0065$, respectively) as determined using real-time RT-PCR. Expression of each gene in control mice was set to 1 ( $n=4$ mice per group; data representative of two independent experiments). 

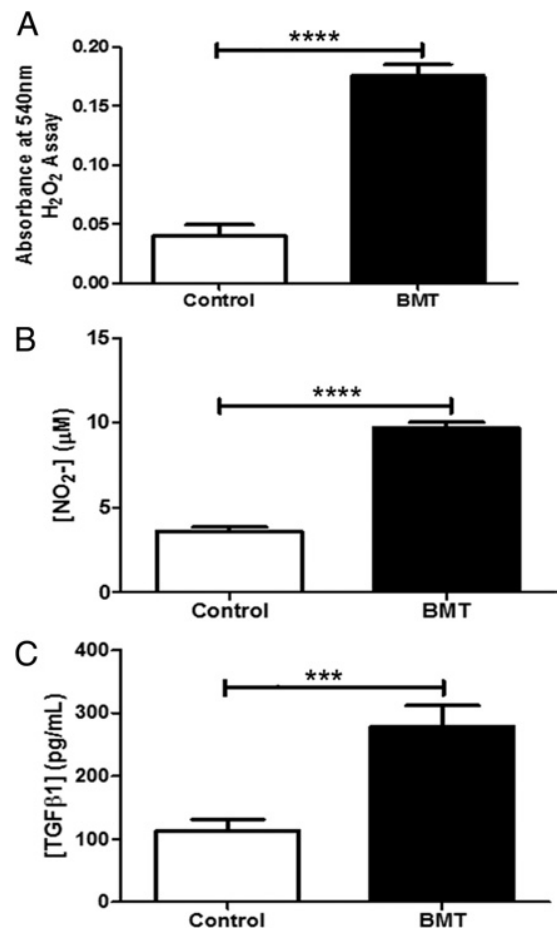

Figure 6. BMT mice exhibited increased $\mathrm{H}_{2} \mathrm{O}_{2}, \mathrm{NO}_{2}{ }^{-}$, and TGF- $\beta 1$ in BAL fluid BAL fluid was harvested from BMT and control mice at day 21 after infection with $5 \times 10^{4}$ pfu MHV-68. The relative levels of $\mathrm{H}_{2} \mathrm{O}_{2}(\mathbf{A}), \mathrm{NO}_{2}(\mathbf{B})$, and total TGF- $\beta 1$ (C) were significantly increased in BAL fluid from BMT mice compared with infected control mice ${ }^{(* * *} P=0.0027$, and ${ }^{* * * * *} P<0.0001$ respectively; $n=$ 5 mice per group; data representative of two independent experiments).

\section{Blocking TGF- $\beta$ Signaling in T Cells Significantly Improves Pneumonitis and Fibrosis in BMT Mice}

To understand whether TGF- $\beta$ was contributing to gammaherpesvirus-induced pneumonitis and fibrosis in this model, we used mice expressing the dnTGF $\beta$ RII transgene in $T$ cells as BMT donors. Using the same conditioning regimen as in previous experiments, recipient BMT mice underwent transplantation using bone marrow from a T-cell dnTGF $\beta R \|$ donor $^{16}$ (expressing the dnTGF $\beta$ RII transgene under the permissive CD4 promoter and blocking TGF- $\beta$ signaling in both CD4 and CD8 T cells). This approach enabled us to determine whether TGF- $\beta$ was promoting pneumonitis via effects on donor $T$ cells at day 21 after infection. We have previously published that whereas wild-type (WT) BMT mice demonstrate reduced ability to control lytic MHV-68 replication in the lung at day 7 after infection, T-cell dnTGF $\beta$ RII BMT mice do not. ${ }^{13}$ At day 21 after infection, we observed a drastic reduction in pneumonitis, fibrosis, and overall histology score in infected BMT recipients of T-cell dnTGF $\beta$ RII bone marrow (Figure 7, A and B). Considering only the fibrosis component of the composite histology score, infected BMT mice scored $2.86 \pm 0.1$ units, whereas infected T-cell dnTGF $\beta$ RII BMT mice scored $1.0 \pm 0.3$ units $(P<$ .001). We next measured levels of TGF- $\beta$ in BAL fluid at day 21 in infected mice. BAL fluid levels of TGF- $\beta$ were diminished on day 21 after infection when donor $\mathrm{T}$ cells were unresponsive to TGF- $\beta$ signaling (Figure 7C). Levels of nitrite were intermediate between control and BMT values (Figure 7D). In addition, expression of arginase 1 and iNOS, markers of alternatively or classically activated macrophages, was also unchanged. When levels of these transcripts were measured using real-time RT-PCR in isolated alveolar macrophages on day 21 after infection and compared with those in control mice normalized to 1 , iNOS levels were $2.7 \pm 0.6$-fold higher and arginase 1 levels were $30.5 \pm 3.5$-fold higher $(n=6)$. These levels are similar to those measured in WT BMT mice (Figure 5). When we considered transcription of collagen 1 and collagen 3 , the T-cell dnTGF $\beta$ RII BMT mice demonstrated reductions when compared with the WT BMT mice; however, in these experiments, the changes did not quite reach statistical significance (Figure 7, E and F).

\section{Pneumonitis and Fibrosis in WT BMT Mice Are Not Related to Regulatory $T$ Cells}

Given the importance of TGF- $\beta$ in the development of pneumonitis and fibrosis in BMT mice and the importance of TGF- $\beta$ in the biology of regulatory T cells (Tregs), we investigated the possible role of Tregs. We have previously demonstrated that Tregs were not impairing clearance of lytic virus at day 7 after infection. ${ }^{13}$ To determine whether Tregs were important for generation of TGF- $\beta$ during latent infection, we injected mice with anti-CD25 or isotype control antibody on day 10 after infection. On day 21 after infection, mice treated with anti-CD25 demonstrated equivalent levels of fibrosis as did mice treated with isotype control (see Supplemental Figure S5A at http://ajp.amjpathol.org). In addition, there were similar increases in TGF- $\beta$ (see Supplemental Figure S5B at http://ajp.amjpathol.org). Nitrite levels in the BAL fluid were reduced, but not significantly (see Supplemental Figure S5C at http://ajp.amjpathol.org). These data indicate that Tregs are not the primary source of TGF- $\beta$ during MHV-68 latency in BMT mice.

\section{Increases in TGF- $\beta$ after Infection in BMT Mice Are from Parenchymal Cells in the Lung}

We next sought to identify the potential cellular source of TGF- $\beta$ in our BMT mice at day 21 after infection. Alveolar macrophages were isolated via $B A L$, and $T$ cells and $B$ cells from lung digests from control and BMT mice on day 21 after infection. These cell populations were cultured for 24 hours, and TGF- $\beta$ was measured in cell supernatants. None of these cell types demonstrated increased production of TGF- $\beta$ when isolated from BMT mice at day 21 after infection (see Supplemental Figure S6, A-C, at http://ajp.amjpathol.org). In addition, culture of total BAL cells (containing additional leukocytes such as neutrophils) at day 21 after infection did not demonstrate increased TGF- $\beta$ (data not shown). These results suggest that parenchymal cells may be the source of increased TGF- $\beta$ production. To determine whether AECs were the source, we attempted to purify AECs from control and BMT mice on day 21 after infection. However, in three separate experiments, only half the number of AECs could be recovered from infected BMT mice compared with control mice (see Supplemental Figure S6D at 
A

A cell DN-TGF $\beta$ RII BMT

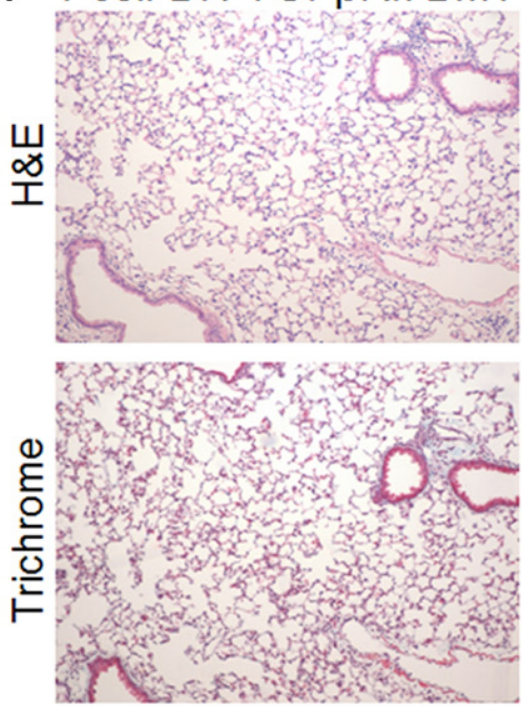

D

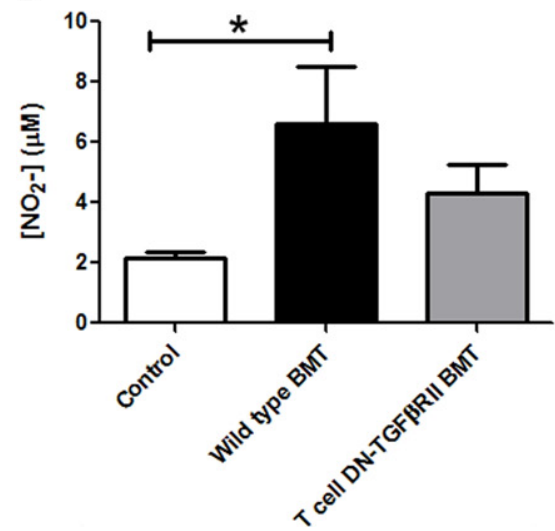

\section{B}

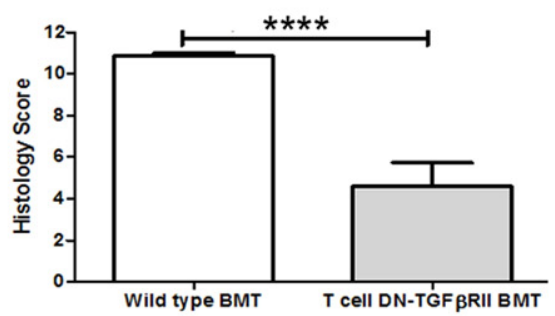

C

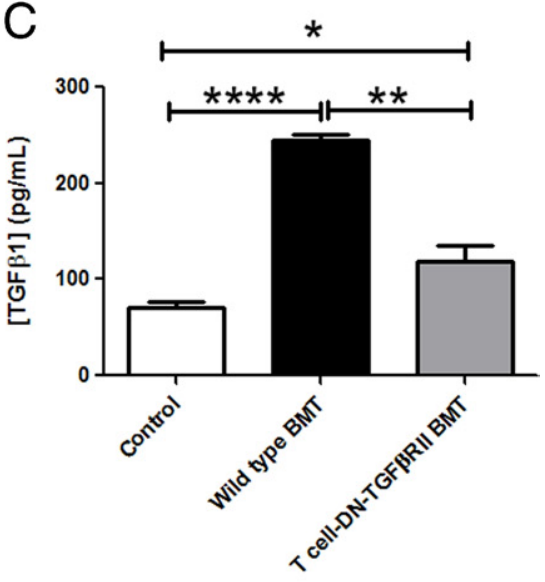

E

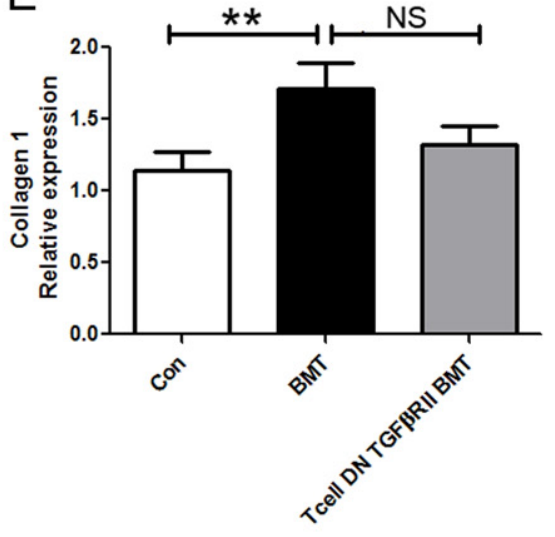

$\mathrm{F}$

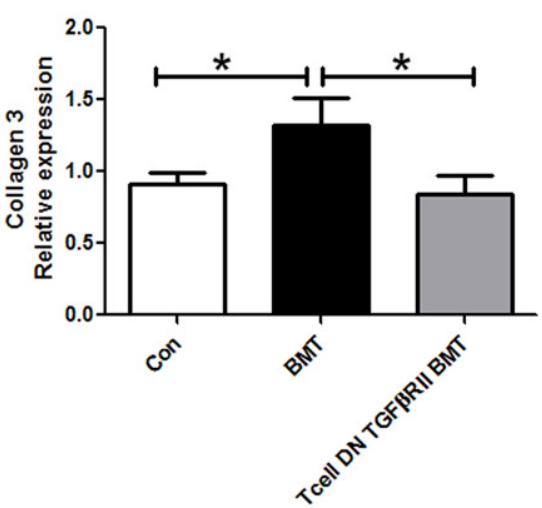

Figure 7. In mice, transplantation of T-cell dnTGF $\beta$ RII bone marrow significantly reduces pneumonitis, fibrosis, and TGF- $\beta$ levels during latent MHV- 68 infection. BMT mice who received T-cell dnTGF $\beta$ RII bone marrow were infected with $5 \times 10^{4}$ pfu MHV- 68 . A: Lungs were harvested at day 21 after infection for histologic analysis and stained using H\&E and Masson's trichrome (magnification $\times 100 ; n=6$ mice; data representative of two independent experiments. B: Lung sections were scored in a blinded fashion by a pathologist (S.F.) on the basis of presence and severity of pathologic features. C: TGF- $\beta$ levels were measured in BAL fluid at day 21 after infection ( $n=4$ or 5 mice per group; data representative of two independent experiments). D: Levels of nitrite were measured in BAL fluid at day 21 after infection ( $n=3$ to 5 mice per group). $\mathbf{E}$ and $\mathbf{F}$ : Expression of collagen 1 or collagen 3 mRNA was measured in lungs collected at day 21 after infection $\left(n=\right.$ at least 10 mice per group; data representative of three experiments; ${ }^{*} P \leq 0.05$, ${ }^{* * *} P \leq 0.01$, **a*k* $P \leq 0.0001)$

http://ajp.amjpathol.org). Of the AECs that were recovered, there were no differences in TGF- $\beta$ production (see Supplemental Figure S6E at http://ajp.amjpathol.org), although we think it likely that the injured AECs which could not be isolated may be a source of TGF- $\beta$ in vivo.

\section{T-Cell dnTGF $\beta R / l$ BMT Mice Demonstrate} Reduced Levels of Apoptosis Compared with BMT Mice after Infection

Our findings of reduced numbers of AECs in BMT mice on day 21 after infection (see Supplemental Figure S6D at http://ajp.amjpathol.org) suggested that epithelial cell injury may contribute to development of pneumonitis and fibrosis. To explore this further, we stained lung sections from control, BMT, and T-cell dnTGF $\beta$ RII BMT mice for apoptosis using a TUNEL assay and
E-cadherin to highlight epithelial cells. Increased levels of apoptosis were noted in BMT mice compared with control mice (Figure 8). Counts of apoptotic cells in lung sections demonstrated that infected control mice exhibited $26 \pm 5.4$ cells per high-power field, whereas BMT mice exhibited $55 \pm 5.6$ apoptotic cells $(P=0.004)$. In addition, there was a trend toward lower levels of apoptosis in the infected T-cell dnTGF $\beta$ RII BMT mice, ie, $38 \pm 2$ cells per high-power field, than in infected WT BMT mice $(P=0.06)$.

\section{CD11c-dnTGF $\beta$ RIl Mice Are Only Modestly} Protected from Virus-Induced Pneumonitis and

\section{Fibrosis}

To determine whether TGF- $\beta$ signaling in CD11c-expressing donor cells including alveolar macrophages, 
Con + MHV-68 day 21

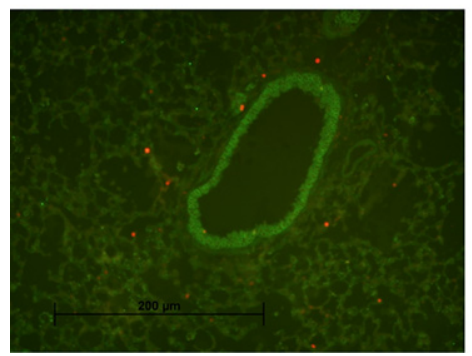

$\mathrm{BMT}+\mathrm{MHV}-68$ day 21

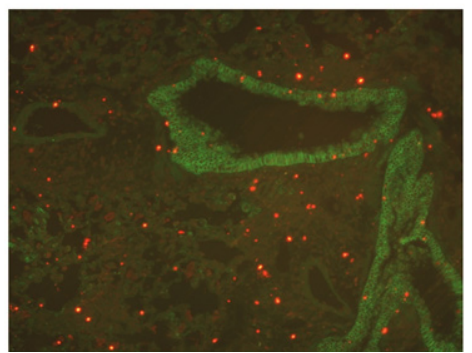

T cell DN TGF $\beta$ RII BMT + MHV-68 dav 21

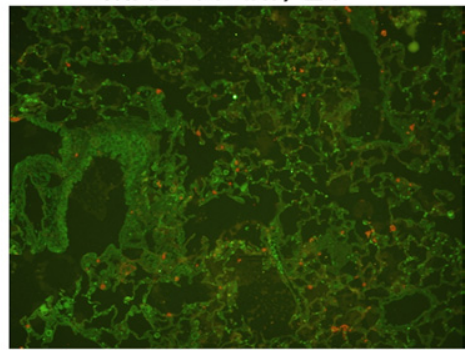

Figure 8. BMT mice demonstrated increased apoptosis at day 21 after infection with MHV-68. Lung sections from control, BMT, or T-cell dnTGF $\beta$ RII BMT mice were stained using FITC-labeled E-cadherin (green) to mark epithelial cells and TUNEL (TMR red) to indicate apoptosis. Overlays are representative of data from two mice in each group.

dendritic cells, and natural killer cells would affect the development of pneumonitis and fibrosis, we transplanted WT or CD11c-dnTGF $\beta$ RII bone marrow into mice and examined the mice at days 7 and 21 after infection with MHV-68. CD11c-dnTGF $\beta$ RII BMT mice demonstrated increased lytic viral replication at day 7 after infection, which is similar to levels in WT BMT mice (see Supplemental Figure S7A at http://ajp. amjpathol.org). Accordingly, these mice demonstrated far less protection from disease (see Supplemental Figure S7B at http://ajp.amjpathol.org) and lower histology score (see Supplemental Figure S7C at http://ajp. amjpathol.org) than did the T-cell dnTGF $\beta$ RII BMT mice (Figure 7).

\section{Within BMT Mice, Lytic Viral Load Corresponds with Subsequent Degree of Pneumonitis and Fibrosis}

Data from the present study demonstrated that T-cell dnTGF $\beta$ RII BMT mice demonstrated restored ability to control Iytic MHV-68 replication ${ }^{13}$ and that these mice are largely protected from development of pneumonitis at day 21 after infection (Figure 7). Correspondingly, CD11c-dnTGF $\beta$ RII BMT mice were not able to restore control of lytic replication and proceed to development of severe pneumonitis and fibrosis (see Supplemental Figure S7 at http://ajp.amjpathol.org). Considered together, these results suggest that initial control of lytic virus can prevent subsequent pneumonitis and fibrosis. To determine whether degree of Iytic replication corresponds with subsequent disease in BMT mice, we infected BMT mice with increasing dosages of virus. We have previously reported that BMT mice challenged with $1 \times 10^{3}$ pfu MHV-68 demonstrate an approximately twofold increase in viral replication at day 7 after infection, BMT mice infected with $5 \times 10^{4} \mathrm{pfu}$ demonstrate an approximately sixfold increase over control mice, and BMT mice infected with $1 \times 10^{6} \mathrm{pfu}$ demonstrate a ninefold increase in lytic virus gene expression. ${ }^{13}$ We now demonstrate that development of lung disease in BMT mice correlates with the ability to control lytic replication. The lower lytic viral dosage is associated with less disease (Figure 9A) and a lower histology score (Figure 9B) at day 21 than noted with the higher viral titer. In addition, lower initial lytic virus results in lower levels of nitrite (Figure 9C) and ultimately in lower TGF- $\beta$ levels in the BAL fluid (Figure 9D). It should be noted that control mice infected with the lower viral dosage exhibit essentially no signs of disease at day 21 after infection (data not shown). Infection of BMT mice with a higher dose of virus, $3 \times$ $10^{5} \mathrm{pfu}$, resulted in death of all mice by day 14 . Together, these findings suggest that impaired ability to control lytic viral replication in BMT mice leads to increased apoptosis and lung damage, increased TGF- $\beta$ levels in the BAL fluid, and ultimately pneumonitis and fibrosis during viral latency.

\section{Discussion}

We have previously demonstrated in our myeloablative syngeneic BMT model that mice have fully restored hematopoietic cell numbers in the lung at 5 weeks after transplantation, yet have increased susceptibility to pulmonary lytic infection with MHV-68 measured at day 7 after challenge. ${ }^{13}$ In the present study, we observed that BMT mice develop severe persistent MHV-68induced pneumonitis during virus latency (days 21 to 49) despite equivalent latent viral loads. By day 21 after infection, BMT mice demonstrate peripheral inflammation in the lung, as well as presence of foamy alveolar macrophages, fibrosis, and diffuse alveolar damage. This phenotype persists even 7 weeks after infection. Compared with infected control mice who have not undergone transplantation, BMT mice exhibit increased infiltration of neutrophils and of CD4, and CD8 cells into the alveolar space during MHV-68 latency. Accordingly, BMT mice demonstrate reduced oxygen saturation during virus latency. Alveolar macrophages from BMT mice are histologically large and foamy, and, as a population, expression of the alternative activation marker arginase 1 precedes expression of the classic activation marker iNOS. BAL fluid from BMT mice during MHV-68 latency contains increased levels of $\mathrm{H}_{2} \mathrm{O}_{2}$ and $\mathrm{NO}_{2}{ }^{-}$, indicating oxidative stress, 
A
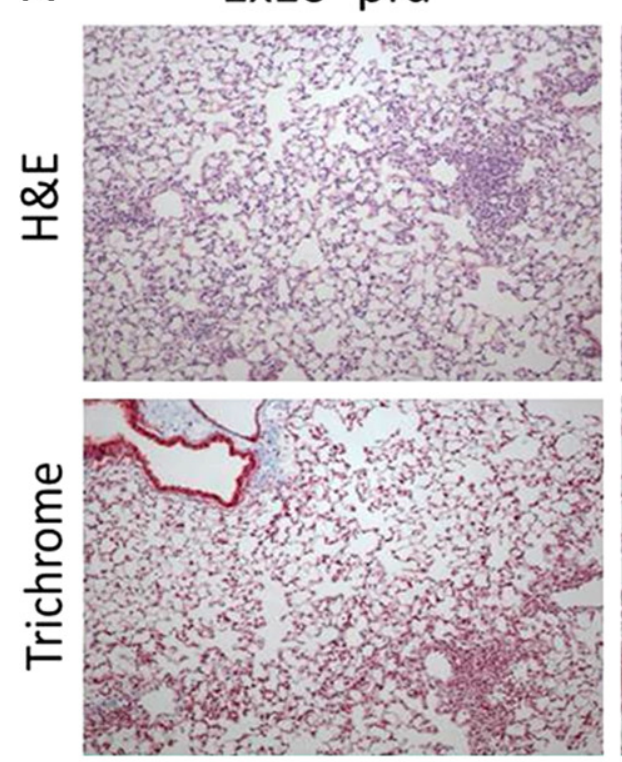

C

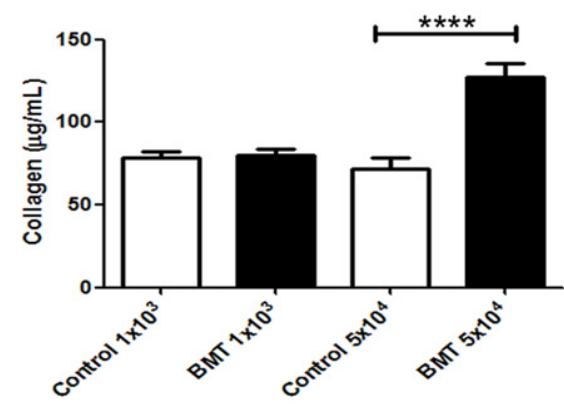

$5 \times 10^{4} \mathrm{pfu}$
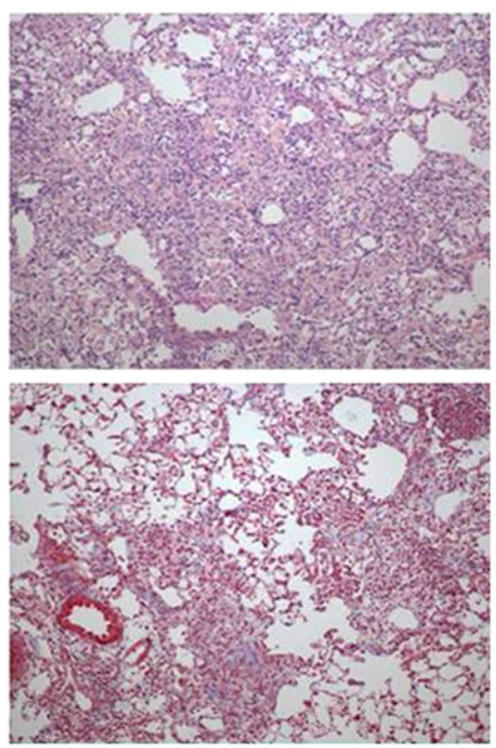

B

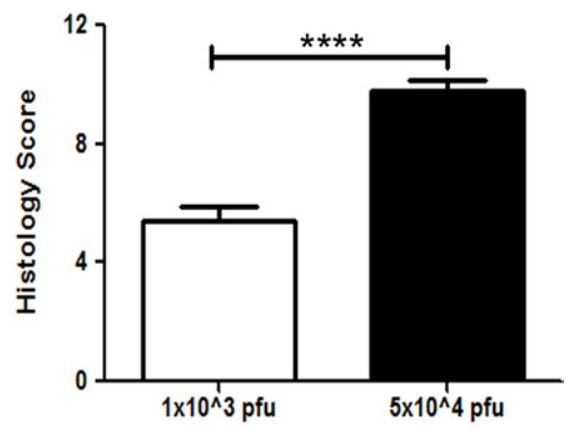

D

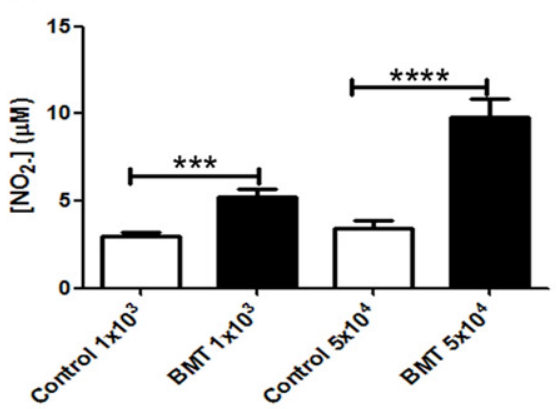

$\mathrm{E}$

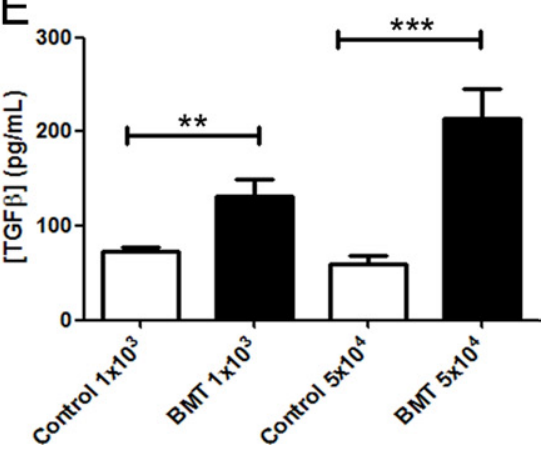

Figure 9. Increasing lytic viral dose worsens subsequent lung disease. BMT mice were infected with $1 \times 10^{3}$ or $5 \times 10^{4}$ pfu MHV- 68 , and measurements were made at day 21 after infection. A: Representative H\&E- and trichrome-stained sections. B: Histology score based on data from five mice demonstrate the higher dosage results in worsened disease. C: Control or BMT mice were infected with both dosages of virus, and collagen content was measured in lungs via hydroxyproline content. Only the $5 \times 10^{4}$ pfu dose of virus caused significant increases in lung fibrosis ( $n=7$ or 8 per group). D: Levels of nitrite were increased in BAL fluid of BMT mice compared with control mice infected with both dosages at day 21 after infection ( $n=7$ or 8 per group). E: Levels of TGF- $\beta$ from BAL fluid were analyzed using an ELISA. TGF- $\beta$ was significantly increased in BAL fluid from BMT mice compared with control mice with both dosages of virus ( $n=7$ or 8 per group; $\left.{ }^{* * *} P \leq 0.01,{ }^{* * * *} P \leq 0.001,{ }^{* * * * *} P \leq 0.001\right)$.

as well as an increase in the pro-fibrotic cytokine TGF$\beta 1$. BMT mice also exhibit increased evidence of apoptosis within the lung. BMT mice that are transplant recipients of bone marrow from T-cell dnTGF $\beta$ RII mice demonstrate a drastic reduction in severity of pneumonitis, whereas recipients of bone marrow from CD11cdnTGF $\beta$ RII mice exhibit only a moderate reduction in pneumonitis severity. The protection in T-cell dnTGF $\beta$ RII BMT mice is associated with less apoptosis and reduced levels of TGF- $\beta$ in the BAL fluid, and a trend toward reduced nitrite production. Considered together, these data suggest that severe gammaherpesvirus-induced pneumonitis can occur in BMT mice long after the lytic phase of virus infection has resolved and that this may be alleviated by blocking TGF- $\beta$ signaling, especially in $T$ cells. We hypothesized that the prevention of disease in the T-cell dnTGF $\beta$ RII BMT mice was associated with the ability of these mice to control lytic MHV-68 replication because severity of disease increased with increasing viral challenge in WT BMT mice.

We have previously reported that BMT mice demonstrated increased susceptibility to lytic MHV-68 infection, as noted by higher expression of lytic viral genes at day 7 after infection, viral immunohistochemistry, and plaque assay. ${ }^{13}$ We now report that these mice have equivalent latent viral loads (Figure 1) at day 21 after infection as control mice given the same dosage of virus. It was surprising to note that BMT mice have equivalent latent viral loads after having increased lytic virus; however, our results are consistent with previous studies that demonstrated that lytic virus titers do not necessarily correlate with latent levels of MHV-68. ${ }^{32,33}$ We hypothesize that much of the lytic replication at day 7 may occur in cell types that do not remain resident in the lung by day 21. It is important to note, however, that while levels of lytic infection may not influence the levels of latent viral load at day 21 with MHV-68, the 
degree of lung damage induced by lytic virus in BMT mice may still be important. In BMT mice, infection with $5 \times 10^{4}$ pfu MHV-68 led to more severe pneumonitis and fibrosis than did infection with $1 \times 10^{3}$ pfu (Figure 9), whereas in control mice, no disease was observed after infection with $1 \times 10^{3}$ pfu virus (data not shown), and only mild disease was noted at the higher dosage (Figure 2). These results highlight that lungs of BMT recipients are uniquely susceptible to induction of viral-induced disease.

Despite observing no difference in latent viral load between control and BMT mice, we noted that BMT mice developed severe persistent pneumonitis and fibrosis during latent MHV-68 infection (Figure 2). It is important to note that in our model, the pneumonitis phenotype was virus-induced. Uninfected BMT mice exhibited no signs of pneumonitis or fibrosis at 2 months after transplantation (Figures 2 and 3). Although irradiated C57BL/6 mice develop irradiationinduced fibrosis, this does not occur until 20 to 30 weeks after irradiation, long after the 8-week point used in our studies. ${ }^{34} \mathrm{~A}$ recent prospective study of pediatric allogeneic HSCT recipients closely monitored respiratory viral infections after transplantation and observed that early respiratory virus infection after transplantation correlated significantly with development of idiopathic pneumonia syndrome and bronchiolitis obliterans in their cohort. Patients had recovered from initial respiratory symptoms before development of later respiratory complications. ${ }^{35}$ It is interesting to speculate that an inflammatory stimulus such as a virus can lead to pneumonitis and lung injury at later time points, even after resolution of the initial lytic insult.

In accordance with the severe inflammatory and fibrotic phenotype in BMT mice at day 21 after infection with MHV-68, our data demonstrate that these mice also exhibit reduced oxygen saturation (see Supplemental Figure S2 at http://ajp.amjpathol.org). It is important to highlight that this reduced oxygen saturation measures values at rest and might be even more dramatic if mice are exercised. The reduced oxygen saturation in our BMT mice correlated with reports of abnormal pulmonary function test results that persist over the long term in HSCT recipients. ${ }^{11}$

In our model, we observed infiltration of inflammatory cells including neutrophils and lymphocytes in the alveolar space during latent MHV-68 infection in BMT mice (Figure 4). The largest lymphocyte population present in the alveolar space in both BMT and control mice was CD8 cells, which are an expanded population during MHV-68 latency. ${ }^{36}$ We speculate that infiltration of these cells to the alveolar space may be indicative of unresolved inflammation due to the initial virus infection because a percentage of CD8 cells were specific for a viral epitope (data not shown). We also observed the presence of foamy alveolar macrophages in lungs of BMT mice (Figure 5) during latent MHV-68 infection. When the alveolar macrophage population was enriched from BMT mice at day 21 after infection, these cells expressed the classic activation marker iNOS, an enzyme that catalyzes production of nitric oxide, as well as the alternative activation marker arginase 1 , an enzyme that promotes fibroblast proliferation (Figure 5B). Classically activated macrophages are thought to promote inflammation, whereas alternatively activated macrophages are associated with wound repair and fibrosis. ${ }^{26,37}$ The kinetics of arginase 1 and iNOS expression suggest that alternatively activated macrophages develop more quickly after infection and that the magnitude of arginase 1 expression is greater than that of iNOS (see Supplemental Figure S3 at $h$ ttp://ajp.amjpathol.org). The dichotomy of function between these macrophage subsets correlates well with the inflammatory and fibrotic phenotypes in the lungs in BMT mice during MHV-68 latency.

Alternatively activated macrophages have been implicated in promoting pulmonary fibrosis during chronic MHV-68 infection in IFN $\gamma \mathrm{R}^{-} /^{-}$mice; the appearance of these macrophages was attributed to the type 2 helper T-cell (Th2) environment and expression of $\mathrm{IL}-13^{27}$ in these Th2-biased mice. In our model, we observed no evidence of up-regulated IL-4 or IL-13 production by BAL cells and alveolar macrophages or in whole-lung homogenates (data not shown). However, we have previously reported a significant decrease in numbers of IFN- $\boldsymbol{\gamma}$-producing CD4 cells in the lungs of BMT mice during lytic MHV-68 infection (day 7 after infection), ${ }^{13}$ which suggests that the development of arginase 1-expressing alveolar macrophages may occur in the absence of an overwhelming Th1 response and not simply in the presence of a Th2 response. It is also possible that the protracted expression of IL-10 in the lungs of BMT mice (data not shown) may drive alternative activation of the alveolar macrophages. ${ }^{38}$ Alveolar macrophages are known to express CD11c: thus, the fact that CD11c-dnTGF $\beta$ RII BMT mice still exhibit evidence of foamy macrophages at histologic analysis of the lungs as part of the composite score (see Supplemental Figure S7 at http://ajp.amjpathol. org) may suggest that TGF- $\beta$ signaling in alveolar macrophages is not required for alternative activation. However, we cannot rule out the possibility that the alternatively activated macrophages may have arisen from CD11c-negative monocytes that were still responsive to TGF- $\beta$ signaling in those transplants.

We also report increased oxidative stress in BMT mice at day 21 after infection with MHV-68, as evidenced by increased levels of $\mathrm{H}_{2} \mathrm{O}_{2}$ and $\mathrm{NO}_{2}{ }^{-}$in $\mathrm{BAL}$ fluid (Figure 6). These reactive intermediates promote tissue damage and have been implicated in promoting pulmonary fibrosis (reviewed by Kliment and Oury ${ }^{39}$ ). For example, in animal studies, reactive nitrogen intermediates stimulated production of TGF- $\beta .{ }^{40}$ Accordingly, we observed a significant increase in levels of TGF- $\beta$ in BAL fluid from BMT mice at day 21 after infection (Figure 6), and kinetic increases in nitrite and TGF- $\beta$ are similar after infection (see Supplemental Figure $S 4$ at $h$ ttp://ajp.amjpathol.org). It is also possible that the increased presence of neutrophils in the BMT mice contributed to the secretion of oxidants into the alveolar space. While ROS were noted in the BMT 
mice, it is unknown how much they contributed to the disease we observed. Compared with infected BMT mice, infected T-cell dnTGF $\beta$ RII BMT mice demonstrate significantly reduced pneumonitis and fibrosis scores. When measuring levels of nitrite in the BAL fluid, the T-cell dnTGF $\beta$ RII BMT mice demonstrated an intermediate phenotype between that of control and BMT mice (Figure 7). Conversely, the anti-CD25treated mice exhibited reduced nitrite levels but not improved fibrosis (see Supplemental Figure S5 at http://ajp.amjpathol.org). Thus, it is not clear whether nitrite alterations have a biological effect on fibrosis. It is also interesting that the T-cell dnTGF $\beta$ RII BMT mice did not demonstrate decreases in the alternative activation marker arginase 1 despite improved pathologic findings. In the final analysis, the factor that most closely tracked with fibrosis and pneumonitis was the level of TGF- $\beta$ observed in the BAL fluid at day 21 in all cases.

Our data demonstrate that blocking of TGF- $\beta$ signaling in T cells in the BMT setting leads to a dramatic reduction in inflammation, fibrosis, and lung histology score (Figure 7). These data suggest direct or indirect involvement of T cells in development of pneumonitis in this model. Previous studies from our laboratory have demonstrated that BMT mice expressed increased levels of TGF- $\beta 1$ in the lung before infection. ${ }^{13}$ Our data suggested that TGF- $\beta$ limited effector Th1 responses to Iytic MHV-68 infection, thus causing an increase in lytic viral load. ${ }^{13}$ Subsequent pneumonitis and fibrosis during latent infection may result from the enhanced lytic virus insult, possibly causing increased epithelial cell destruction, the unresolved inflammatory response that accompanies the increased lytic viral load, or altered wound repair mechanisms to control tissue damage. Support for these hypotheses come from several of our observations: i) increasing lytic viral pfu correlates with increased disease during latency in BMT mice (Figure 9); ii) infected BMT mice exhibit evidence of apoptosis that is lessened in T-cell dnTGF $\beta$ RII BMT mice and control mice (Figure 8); iii) fewer AECs can be isolated from infected BMT mice than from infected control mice at day 21 (see Supplemental Figure S6 at $h t t p: / /$ ajp.amjpathol.org); and iv) the inflammatory response in BMT mice is much greater than that in infected control mice (Figure 4). The T-cell dnTGF $\beta$ RII BMT mice express decreased levels of TGF- $\beta 1$ before infection and exhibit restored numbers of Th1 cells in response to Iytic MHV-68 infection. ${ }^{13}$ These mice also have reduced levels of TGF- $\beta$ in BAL fluid at day 21 after infection. While we have not definitively proved the source of increased TGF- $\beta$, we have ruled out the contribution of Tregs (see Supplemental Figure S5 at http://ajp.amjpathol.org), alveolar macrophages, and B and T cells (see Supplemental Figure S6 at http:// ajp.amjpathol.org), which suggests that the source is a parenchymal cell type in the lung. We speculate that injured alveolar epithelial cells that are unable to be isolated at 21 days after infection may contribute; however, it is also possible that endothelial or mesenchymal cell types may participate as well.
We also observed a modest but significant reduction in lung histology score in BMT mice that received donor cells expressing a dnTGF $\beta$ RII transgene under the CD11c promoter (see Supplemental Figure S7 at $h t t p: / /$ ajp.amjpathol.org). When analyzing the response to lytic infection, we observed that CD11c-dnTGF $\beta$ RII BMT mice demonstrated high lytic viral loads at day 7 after infection, similar to that in WT BMT mice (see Supplemental Figure S7A at http://ajp.amjpathol.org). These data suggest that TGF- $\beta$ signaling has a small role in CD11c-expressing cells to control lytic infection. However, the fact that the CD11c-dnTGF $\beta$ RII BMT mice demonstrated a modestly improved pneumonitis phenotype suggests that some CD11c-expressing cell type may influence lung disease at a later time. We do not yet know whether the improved phenotype of the CD11c-dnTGF $\beta$ RII BMT mice is due to blockade of TGF- $\beta$ signaling in alveolar macrophages, dendritic cells, or natural killer cells; however, the pathologist (S.F.) was still able to detect foamy alveolar macrophages at histologic evaluation of the CD11cdnTGF $\beta$ RII BMT mice. However, whether these mice show reduced ROS generation or alternatively activated macrophages remains a formal possibility and will require further study.

Previous work in an allogeneic GvHD model demonstrated that induction of herpes simplex virus type 1 (HSV-1)-induced pneumonitis late after transplantation was also mediated by the effects of TGF- $\beta .{ }^{15}$ Although our model also implicates TGF- $\beta$ in promoting pneumonitis, there are several important differences between the models. Pneumonitis in the HSV-1 model developed at day 5 to 7 after infection and involved periluminal but not parenchymal inflammation and exhibited no indication of fibrosis. In addition, those authors concluded that pneumonitis in the HSV-1 model resulted from GvHD because allogeneic BMT mice without GvHD did not develop lung disease. ${ }^{15}$ However, because of the difference in timing, it is interesting to speculate that fibrosis and lung disease in the allogeneic mice without GvHD would be manifested later after-HSV-1 as well.

Studies have indicated a correlation between GVHD and noninfectious lung complications such as idiopathic pneumonia syndrome and bronchiolitis obliterans. ${ }^{7}$ In addition, studies have also reported occurrence of idiopathic pneumonia syndrome in transplant recipients after autologous transplantation, ${ }^{7-9}$ which suggests that pneumonitis development in HSCT recipients is multifactorial. In our model, we hypothesized that up-regulation of TGF- $\beta$ pre-infection in the lungs of BMT mice resulted in poor control of lytic viral replication. In turn, this leads to lung injury, inflammatory cell accumulation, alternative activation of macrophages, induction of ROS, and further increases in TGF- $\beta$ production during viral latency. The end result is persistent pneumonitis and fibrosis that diminish lung function. Blocking TGF- $\beta$ signaling, especially in T cells, in the BMT setting is sufficient to significantly reduce virus-induced pathologic changes in this model. These results suggest that anti-TGF- $\beta$ therapy 
may be effective in limiting the complications of pneumonitis and fibrosis in the HSCT setting. The focus of future studies will be to determine whether TGF- $\beta$ blockade at late times (during latency) is efficacious in limiting lung disease.

\section{Acknowledgments}

We thank Drs. Keith Bishop and Susan Faust for providing the T-cell dnTGF $\beta$ RII mice, and Dr. Jason Weinberg for providing the protocol and plasmid for quantification of viral genomes.

\section{References}

1. Copelan EA: Hematopoietic stem-cell transplantation. N Engl J Med 2006, 354:1813-1826

2. Barfield RC, Kasow KA, Hale GA: Advances in pediatric hematopoietic stem cell transplantation. Cancer Biol Ther 2008, 7:15331539

3. Soubani AO, Miller KB, Hassoun PM: Pulmonary complications of bone marrow transplantation. Chest 1996, 109:1066-1077

4. Sharma S, Nadrous HF, Peters SG, Tefferi A, Litzow MR, Aubry MC, Afessa B: Pulmonary complications in adult blood and marrow transplant recipients: autopsy findings. Chest 2005, 128:13851392

5. Roychowdhury M, Pambuccian SE, Aslan DL, Jessurun J, Rose AG, Manivel JC, Gulbahce HE: Pulmonary complications after bone marrow transplantation: an autopsy study from a large transplantation center. Arch Pathol Lab Med 2005, 129:366-371

6. Wingard JR, Hsu J, Hiemenz JW: Hematopoietic stem cell transplantation: an overview of infection risks and epidemiology. Infect Dis Clin North Am 2010, 24:257-272

7. Afessa B, Litzow MR, Tefferi A: Bronchiolitis obliterans and other late onset non-infectious pulmonary complications in hematopoietic stem cell transplantation. Bone Marrow Transplant 2001, 28: 425-434

8. Wong R, Rondon G, Saliba RM, Shannon VR, Giralt SA, Champlin RE, Ueno NT: Idiopathic pneumonia syndrome after high-dose chemotherapy and autologous hematopoietic stem cell transplantation for high-risk breast cancer. Bone Marrow Transplant 2003, 31:11571163

9. Bilgrami SF, Metersky ML, McNally D, Naqvi BH, Kapur D, Raible D, Bona RD, Edwards RL, Feingold JM, Clive JM, Tutschka PJ: Idiopathic pneumonia syndrome following myeloablative chemotherapy and autologous transplantation. Ann Pharmacother 2001, 35:196201

10. Limper AH: Chemotherapy-induced lung disease. Clin Chest Med 2004, 25:53-64

11. Gower WA, Collaco JM, Mogayzel PJ Jr: Lung function and late pulmonary complications among survivors of hematopoietic stem cell transplantation during childhood. Paediatr Respir Rev 2010, 11:115122

12. Marras TK, Szalai JP, Chan CK, Lipton JH, Messner HA, Laupacis A: Pulmonary function abnormalities after allogeneic marrow transplantation: a systematic review and assessment of an existing predictive instrument. Bone Marrow Transplant 2002, 30:599607

13. Coomes SM, Wilke CA, Moore TA, Moore BB: Induction of TGFbeta 1 , not regulatory $T$ cells, impairs antiviral immunity in the lung following bone marrow transplant. J Immunol 2010, 184:51305140

14. Coomes SM, Moore BB: Pleiotropic effects of transforming growth factor-beta in hematopoietic stem-cell transplantation. Transplantation 2010, 90:1139-1144

15. Adler H, Beland JL, Kozlow W, Del-Pan NC, Kobzik L, Rimm IJ: A role for transforming growth factor-beta1 in the increased pneumonitis in murine allogeneic bone marrow transplant recipients with graft-versus-host disease after pulmonary herpes simplex virus type 1 infection. Blood 1998, 92:2581-2589
16. Gorelik L, Flavell RA: Abrogation of TGFbeta signaling in T cells leads to spontaneous T cell differentiation and autoimmune disease. Immunity 2000, 12:171-181

17. Laouar Y, Sutterwala FS, Gorelik L, Flavell RA: Transforming growth factor-beta controls $T$ helper type 1 cell development through regulation of natural killer cell interferon-gamma. Nat Immunol 2005, 6:600-607

18. Ojielo Cl, Cooke K, Mancuso P, Standiford TJ, Olkiewicz KM, Clouthier S, Corrion L, Ballinger MN, Toews GB, Paine R III, Moore BB: Defective phagocytosis and clearance of Pseudomonas aeruginosa in the lung following bone marrow transplantation. J Immunol 2003, 171:4416-4424

19. Ballinger MN, Aronoff DM, McMillan TR, Cooke KR, Olkiewicz K, Toews GB, Peters-Golden M, Moore BB: Critical role of prostaglandin E2 overproduction in impaired pulmonary host response following bone marrow transplantation. J Immunol 2006, 177:54995508

20. Kolodsick JE, Toews GB, Jakubzick C, Hogaboam C, Moore TA, McKenzie A, Wilke CA, Chrisman CJ, Moore BB: Protection from fluorescein isothiocyanate-induced fibrosis in IL-13-deficient, but not IL-4-deficient, mice results from impaired collagen synthesis by fibroblasts. J Immunol 2004, 172:4068-4076

21. Thrall RS, McCormick JR, Jack RM, McReynolds RA, Ward PA: Bleomycin-induced pulmonary fibrosis in the rat: inhibition by indomethacin. Am J Pathol 1979, 95:117-130

22. Moore BB, Peters-Golden M, Christensen PJ, Lama V, Kuziel WA Paine R III, Toews GB: Alveolar epithelial cell inhibition of fibroblast proliferation is regulated by MCP-1/CCR2 and mediated by PGE2. Am J Physiol Lung Cell Mol Physiol 2003, 284:L342-349

23. Nguyen Y, McGuffie BA, Anderson VE, Weinberg JB: Gammaherpesvirus modulation of mouse adenovirus type 1 pathogenesis. Virology 2008, 380:182-190

24. Stoolman JS, Vannella KM, Coomes SM, Wilke CA, Sisson TH, Toews GB, Moore BB: Latent infection by yherpesvirus stimulates profibrotic mediator release from multiple cell types [published online ahead of print October 2010]. Am J Physiol Lung Cell Mol Physiol 2011, 300: L274-L285

25. Vannella KM, Luckhardt TR, Wilke CA, van Dyk LF, Toews GB, Moore BB: Latent herpesvirus infection augments experimental pulmonary fibrosis. Am J Respir Crit Care Med 2010, 181:465-477

26. Gordon S, Martinez FO: Alternative activation of macrophages: mechanism and functions. Immunity 2010, 32:593-604

27. Mora AL, Torres-Gonzalez E, Rojas M, Corredor C, Ritzenthaler J, Xu J, Roman J, Brigham K, Stecenko A: Activation of alveolar macrophages via the alternative pathway in herpesvirus-induced lung fibrosis. Am J Respir Cell Mol Biol 2006, 35:466-473

28. Psathakis K, Mermigkis D, Papatheodorou G, Loukides S, Panagou P, Polychronopoulos V, Siafakas NM, Bouros D: Exhaled markers of oxidative stress in idiopathic pulmonary fibrosis. Eur J Clin Invest 2006, 36:362-367

29. Carpenter M, Epperly MW, Agarwal A, Nie S, Hricisak L, Niu Y, Greenberger JS: Inhalation delivery of manganese superoxide dismutase-plasmid/liposomes protects the murine lung from irradiation damage. Gene Ther 2005, 12:685-693

30. Border WA, Noble NA: Transforming growth factor beta in tissue fibrosis. N Engl J Med 1994, 331:1286-1292

31. Martin M, Lefaix J, Delanian S: TGF-beta1 and radiation fibrosis: a master switch and a specific therapeutic target? Int J Radiat Oncol Biol Phys 2000, 47:277-290

32. Stevenson PG, Belz GT, Castrucci MR, Altman JD, Doherty PC: A gamma-herpesvirus sneaks through a $\mathrm{CD} 8(+)$ T cell response primed to a lytic-phase epitope. Proc Natl Acad Sci USA 1999, 96:9281-9286

33. Clambey ET, Virgin HWT, Speck SH: Disruption of the murine gammaherpesvirus $68 \mathrm{M} 1$ open reading frame leads to enhanced reactivation from latency. J Virol 2000, 74:1973-1984

34. Moore BB, Hogaboam CM: Murine models of pulmonary fibrosis Am J Physiol Lung Cell Mol Physiol 2008, 294:L152-160

35. Versluys $A B$, Rossen JW, van Ewijk $B$, Schuurman R, Bierings $M B$, Boelens JJ: Strong association between respiratory viral infection early after hematopoietic stem cell transplantation and the development of life-threatening acute and chronic alloimmune lung syndromes. Biol Blood Marrow Transplant 2010, 16:782-791 
36. Doherty PC, Christensen JP, Belz GT, Stevenson PG, Sangster MY: Dissecting the host response to a gamma-herpesvirus. Philos Trans $R$ Soc Lond B Biol Sci 2001, 356:581-593

37. Martinez FO, Helming L, Gordon S: Alternative activation of macrophages: an immunologic functional perspective. Annu Rev Immunol 2009, 27:451-483

38. Schreiber T, Ehlers S, Heitmann L, Rausch A, Mages J, Murray PJ, Lang R, Holscher C: Autocrine IL-10 induces hallmarks of alternative activation in macrophages and suppresses antituberculosis effector mechanisms without compromising T cell immunity. J Immunol 2009 183:1301-1312

39. Kliment CR, Oury TD: Oxidative stress, extracellular matrix targets, and idiopathic pulmonary fibrosis. Free Radic Biol Med 2010, 49:707-717

40. Hsu YC, Wang LF, Chien YW: Nitric oxide in the pathogenesis of diffuse pulmonary fibrosis. Free Radic Biol Med 2007, 42:599-607 